\title{
Alves, L. F. (Ed.) (2016). Fotografias em obras DE EDUARDo SOUTO DE MOURA. MATOSINHOS: Scopio EDITIONS
}

\author{
Anabela Veloso Rodrigues
}

Published in June 2016 by Scopio Editions, the book of Luis Ferreira Alves, Fotografias em obras de Eduardo Souto de Moura [Photography of the architecture of Eduardo Souto de Moura] fits in the category of Architectural Photography.

As an Author's Book Collection, emerges by the publisher to disclose and promote the documentary and artistic photography in the scope of Architecture, City and Territory, proposing to the authors, in this case to Luís Ferreira Alves, the challenge of creating a work that could spark, on those who are going to receive it, an interpretative observation on and about Architectural Photography and, therefore, on the convergence of both practices and the emotional connection between photographers and architects.

Aligned in this sense, converges in this work photography and architecture, stating by visual means the complicity between a photographer and an architect.

Luís Alves was born in 1938 in Valadares, Vila Nova de Gaia, currently living in Oporto. Among his many passions, such as sailing and the cinema, he early devoted himself to photography.

Although as amateur, probably with a more sociological approach, he was already revealing on his work a special sensitivity to the understanding of a work of architecture, its concept within a period of time, its existence in space, the relation of the architect with the work, and the challenge to transform any movable element into something static, in an observer mode, but felt as if we were living every detail.

It is with Pedro Ramalho, architect and author of several works in the scope of Housing, Equipment and Town Planning, and with a remarkable participation on the SAAL Process-Architecture and participation 1974-1976, that emerges Luís Ferreira Alves in the context of the portuguese architecture, more precisely, of architectural photography.

As long-standing friends, Pedro Ramalho proposes to Luís a photographic record of his work, with the aim to present it in a Seminar organized by the Oporto Fine Arts School. The idea was to display a set of slides under a less formal perspective and which could lead to a filmic journey of senses.

Luís Ferreira Alves, an enthusiast of the cinema, and with a professional background at Cineclub of Oporto as a seccionist and co-founder, would be the helmsman of the journey, which result became a success and, therefore, in a set of photograph orders by other architects. Luís Ferreira Alves crosses the line of amateurism and starts his professional practice, collaborating with architects throughout several decades. 
It is from this relation between architects, architecture and photography that the book of Luís Ferreira Alves, Fotografias em obras de Eduardo Souto de Moura [Photography of the architecture of Eduardo Souto de Moura], arises.

Presented to the public in a dense, solid and rigorous support the book reveals a harmonious interior, fulfilled with affections and pleasure, provided by our senses before a work of art. On this basis, the book introduces us into an exploratory journey through the works of Eduardo Souto de Moura.

In this sense, the author reveals that "this is a book of photography in architecture. This is not a book of architecture. This is a book of photography generated on the architecture of Eduardo Souto de Moura" (Alves, 2016, p. 7). This revelation certifies the veracity of his complicity, his way of living architecture and its author, without forgetting his references (the source of his works) and the agreement of himself with architecture and photography. It is almost like a disclosure of the author.

If we want to establish stages on this journey (the book) we can place them on three plans. In the foreground, the recognition of an author, with a testimony from his peers and his devotion to photography in architecture; in the middle ground, the journey through the work of Eduardo Souto de Moura; and in the background, the confirmation of a relationship between architecture and photography.

Being the book a visual document with a very proper language and grammar, it may be considered as a written declaration by means of images, as if it was a narrative. It is the confirmation of the existence and communion between a photographic work and an architectural work and, thus, the existence of complicity between these two authors.

The first pages show up. The honourable welcome are author's words which are rapidly converted into an emotional confession of the hard process of quest for the analysis and selection of the best photographs to pay tribute to the architect. Hand in hand with the text, the first image appears. In the foreground, a concrete wall with an advertising billboard, with the inscription Why not? (Alves, 2016, p. 6). In the background, the Burgo building. Why not now the celebration of Photography in Architecture.

Then, the tributes. Emotional words from his peers, the architects, the share of great memories, acts as a synonym of this bond that lasts over decades.

This bond is developed on the basis of the sense of perception and how photographer and architect address and receive, in a first draft phase, the impression of the place where the work will be born. Whether if it is an architectural work or a photograph, and although founded on different materials, both compete towards the same purpose, the construction of the work.

Other architectural photographers preceded Luís Ferreira Alves, such as Teófilo Rego (1914-1993), also involved with Architecture and who collaborated with several architects from Oporto, contributing to the democratization of architecture and photography by means of his work. Other names are presented. Mário Novais (1899-1967) and Horácio Novais (1910-1988), these in Lisbon, and both working under the aegis of the orders from architects; and Orlando Ribeiro (1911-1997) with a geographic approach to Architecture, and who, by means of his photographs, enabled architects to have a geographical view of the territory. 
At international level, other names must be mentioned such as Walker Evans (19031975), writer, who became devoted to Photography, documenting under a deep emotion and distance the poetry of the environment of a city in the United States of America; Lucien Hervé (1910-2007) who, for 16 years, has documented the works of Le Corbusier; Eugène Atget (1857-1927) who, besides having collaborated with several architects, became known for diverging from the human purpose, to devote his photographic work to the streets of Paris.

Finally, Gabriele Basílico (1944-2013) who, despite being an architect, worked Architecture through a camera.

Throughout the history of photography, and in this case the photography of architecture, there are several examples of this consolidation of partnerships between photographers and architects and their recognition as main players in Architecture.

We move on this journey. We reach the work of Eduardo Souto de Moura, architect from Oporto, born in 1952, having received over his career several awards among which the Pritzker Prize in 2011.

The series of photographs in this book is a celebration of photography and architecture, becoming a visual melody.

Image by image, comes the meditation, the call for the analysis, because photography is not only about the work in itself, but also about the sensorial experience that embraces us when we course it.

The photographs of Luís Ferreira Alves have this gift. They lead us to the experience of space without being there, and to make it happen, it is necessary to master a set of tools in order to offer to the observing reader a pleasant and prolonged experience while turning the pages of this book.

The sense of humour is always there, even remaining hidden from light, fundamental basis on his photographs. The composition is also clear, sometimes graphical. Between black and white, the presence of the colour prevails. The perspective is the story. The one that sets the distance, provides us reference points, happenings, places us in the position of the observer and in the place of the photographer. Through his photographs, we feel closer to the smell of the places and the texture of the materials.

These visual records, followed by the textual presence of the sharing moments and talks with the architect, or simply by accident, drive us to other references. Or because we are still unaware of them, or because they are forgotten, they come to us by means of the text, allowing us to reflect on those associations, as it is the case of the Metro stations, to which Luís Ferreira Alves calls as "submerged Cathedrals" (Alves, 2016, p. 72), and that lead us towards a poetic conceptual approach to the work.

On this tour throughout photographs, a glimpse of Jacques Tati sends us to Playtime, by means of a sequence of reflexes of the bustling city on the glazed building and thus, the impossibility of living it (the city) or to reach it (the work) (Alves, 2016, p. 92).

This set of emotional textual records also accommodates a praise to the steady crematorium in Kortrijk, in Belgium, (Alves, 2016, p. 184), subtly resting on the landscape, and sublimely described photographically. Then, a pure rapture expression by a house in Senhora da Hora (Alves, 2016, p. 220). 
We proceed with the photographs. There, the maturity of the author giving space for analysis. It is a visual practice. Photograph by photograph, he adopts the same methodology based on the discovery of every single space, on every detail. Studies the work, comprehends and locates his own story, inhabits it, abstracts himself from interferences, absorbs the elements that are part of the work. Cautiously, follows a path (the space) depending on the natural or artificial light. Elects perspectives and angles, foregrounds and backgrounds, simulates composition, observes the natural and artificial details, stands before the work and records it photographically, blocking out any act of shooting impulsively.

At the end, checks the result. In short, it is a contemplation process $f$ the work, from the beginning to the end.

It is in the light of this practice that Luís Ferreira Alves introduces us the last plan of this journey, inviting the observing reader to rehearse a series of procedures when approaching architecture and photography.

The exercise to complement architecture with photography based on the principle of an order and, therefore, the intersection of these two practices, culminates in the purpose of bringing more visibility to the architectural work, with all that this process entails.

The exploration of the work by means of a camera, as an extension of the project, has always been a challenge for photographers. Shulman (1910-2009) or Hedrich and Blessing, who communicated through their cameras the architecture of Albert Kahn (1860-1940), Frank Lloyd Wright (1867-1959), Ludwig Mies Van Der Rohe (1886-1969), Eliel (1873-1950) and Eero Saarinen (1910-1961), Raphael Soriano (1904-1988), Minoru Yamasaki (1912-1986), Pierre Koenig (1925-2004), boost the works of these architects to a state of contemplation that still lasts today.

The task has not been easy in the past, it is certainly not easy today, and it will never be, because when different practices are meet, in this case photography and architecture, requirements, needs and wills arise from both sides.

We may even consider it as a painful process, since the achievement of perfection and the connection to the work can be lost at any time.

Luís Ferreira Alves does not seem vulnerable to this event. The photographic act enables him a prior observation on and about the architectural work and its master.

But it must be always about photography...

Translated by Anabela Veloso Rodrigues

\section{BIOGRAPHICAL NOTE}

Anabela Veloso Rodrigues is a teacher, trainer and translator of english language, broadening her activity to Communication and Linguistic Support in an Architecture office.

Graduated in Portuguese and English at the University of Minho, she is presently attending a Master's degree in Communication, Arts and Culture at the same University, 
currently being developing a Master Thesis on Architectural Photography, a Case Study on the photographer Luís Ferreira Alves.

E-mail: ana.rodg@gmail.com

Universidade do Minho, Campus de Gualtar, 4710-057 Braga, Portugal

* Submited: 18-10-2016

* Accepted: 23-01-2017 